\title{
PENUMBUHAN WIRAUSAHA BARU \\ DI LINGKUNGAN KELURAHAN SEMBUNGHARJO GENUK
}

\author{
Pancawati Hardiningsih $^{1 *}$, Ceacilia Srimindarti ${ }^{1}$, RR Dewi Handayani ${ }^{2}$, Askar Yunianto ${ }^{1}$ \\ ${ }^{1}$ Fakultas Ekonomika dan Bisnis Unisbank \\ Jalan Kendeng V Bendan Ngisor 50233 Semarang Jawa Tengah \\ ${ }^{2}$ Fakultas Teknik Informatika Unisbank \\ Jalan Kendeng V Bendan Ngisor 50233 Semarang Jawa Tengah \\ *Email: pancawati@edu.unisbank.ac.id
}

\begin{abstract}
Abstrak
Kewirausahaan perlu dikembangkan dalam rangka mensiasati terbatasnya lapangan kerja. Salah satu kegiatan wirausaha yang dapat dilakukan adalah model bisnis kanvas. Kewirausahaan adalah proses yang dinamis untuk menciptakan sesuatu produk baru, cara produksi baru, menyusun manajemen operasi untuk pengadaan produk baru, serta cara memasarkan produk tersebut. Jiwa dan watak kewirausahaan tersebut dipengaruhi oleh keterampilan, kemampuan, atau kompetensi. Kompetensi ditentukan oleh pengetahuan dan pengalaman berbisnis. Seorang wirausahawan adalah seseorang yang memiliki jiwa dan kemampuan tertentu dalam berkreasi dan berinovasi. Salah satu kegiatan wirausaha yang dapat dilakukan adalah model bisnis kanvas. Oleh karena itu kegiatan pengabdian ini dilakukan dalam rangka menangkap peluang bisnis kanvas. Kegiatan pengabdian dilakukan di Kelurahan Sembungharjo Kecamatan Genuk. Peserta pelatihan diikuti oleh ibu-ibu di wilayah kelurahan Sembungharjo. Waktu pelaksanaan kegiatan pengabdian masyarakat mulai dari tahap persiapan materi, tahap pelaksanaan hingga tahap penyelesaian yaitu pembuatan laporan akhir yang memerlukan waktu kurang lebih 2 bulan. Peserta pelatihan mempraktekkan secara langsung materi yang diberikan mengenai BMC. Pelatihan diharapkan bisa dikembangkan dengan memberikan pelatihan berupa pembuatan anggaran untuk memulai usaha dan pembukuan sederhana dari usaha yang akan dijalankan sehingga akan mengarah pada pembuatan laporan keuangan dan masalah perhitungan pajak hingga sampai pelaporan pajak.
\end{abstract}

\section{Kata kunci: kewirausahaan, model bisnis kanvas, SWOT}

\section{PENDAHULUAN}

Kewirausahaan adalah suatu proses dalam melakukan atau menciptakan sesuatu yang baru dengan cara kreatif dan penuh inovasi yang memberikan manfaat bagi orang lain dan bernilai tambah. Suatu sikap mental seseorang yang memiliki kreativitas, aktif, bercipta daya untuk membuat sesuatu yang unik dan baru serta dapat bermanfaat bagi banyak orang. Kewirausahaan adalah proses yang dinamis untuk menciptakan sesuatu yang disertai tenggang waktu, modal, sumber daya dan juga risiko. Wirausaha adalah orang yang melakukan aktivitas wirausaha yang dicirikan dengan pandai atau berbakat mengenali produk baru, menentukan cara produksi baru, menyusun manajemen operasi untuk pengadaan produk baru, memasarkannya, serta mengatur permodalan operasinya.

Untuk menjadi wirausahawan yang berhasil, maka persyaratan utama yang harus dipenuhi adalah memiliki jiwa dan watak kewirausahaan. Jiwa dan watak kewirausahaan tersebut dipengaruhi oleh keterampilan, kemampuan, atau kompetensi. Kompetensi itu sendiri ditentukan oleh pengetahuan dan pengalaman berbisnis. Seorang wirausahawan adalah seseorang yang memiliki jiwa dan kemampuan tertentu dalam berkreasi dan berinovasi. Ia adalah seseorang yang memiliki kemampuan untuk menciptakan sesuatu yang baru dan berbeda (ability to create the new and different) atau kemampuan kreatif dan inovatif.

Kemampuan kreatif dan inovatif tersebut secara riil tercermin dalam kemampuan dan kemauan untuk memulai berbisnis (start-up), kemampuan untuk mengerjakan sesuatu yang baru (creative), kemauan dan kemampuan untuk mencari peluang (opportunities), kemampuan dan keberanian untuk menanggung risiko (risk bearing) dan kemampuan untuk mengembangkan ide dan meramu sumber daya yang tersedia. Kemauan dan kemampuan tersebut diperlukan terutama untuk: 
1. Melakukan proses/teknik baru (the new technique);

2. Menghasilkan produk atau jasa baru (the new product or new service);

3. Menghasilkan nilai tambah baru (the new value added);

4. Merintis usaha baru ( the new business) yang mengacu pada pasar; dan

5. Mengembangkan organisasi baru (the new organization).

Perencanaan bisnis (business plan) diperlukan untuk merencanakan kemampuan, kebutuhan dan keuntungan yang diharapkan dari bisnis yang akan dikelola. Perencanaan bisnis untuk melihat kemampuan sumber daya yang dimiliki, kekuatan, peluang dari bisnis serupa dan kompetitor yang dihadapi serta kelemahan yang diharapkan bisa menjadi kekuatan untuk berinovasi dalam bisnis.

Business plan dapat dijadikan blue print bisnis dari yang sedang berjalan atau berkembang ataupun yang baru dibangun. Perusahaan yang akan dibuat memiliki tujuan apa / visi apa, bagaimana cara mencapai tujuan tersebut dan siapa saja anggota tim yang terlibat serta kapan bisnis dapat memulai memenuhi tujuannya.

Salah satu perangkat analisis yang bisa membantu untuk menemukan model bisnis yang tepat adalah model bisnis kanvas. Model bisnis ini diperkenalkan oleh Alexander Osterwalder dalam bukunya yang berjudul Business Model Generation. Model bisnis bisa dituangkan dalam framework sederhana untuk mempresentasikan elemen-elemen penting yang terdapat dalam sebuah model bisnis yang tujuan utamanya adalah menghasilkan profit bagi pemain bisnis. Model Bisnis Kanvas adalah sebuah manajemen startegi bisnis yang memungkinkan kita untuk menggambarkan, mendesain kemudian mengerucutkan beberapa aspek bisnis menjadi satu startegi bisnis yang utuh. Dengan memodelkan bisnis yang sudah dijalankan oleh para IKM untuk bisa mengukur kekuatan, kelemahan, tantangan dan sumberdaya yang dimiliki serta keberlanjutan usaha.

Pemberdayaan masyarakat adalah upaya untuk memberikan daya (empowerment) atau penguatan (strengthening) kepada masyarakat. Pemberdayaan masyarakat juga diartikan sebagai kemampuan individu yang bersenyawa dengan masyarakat dalam membangun keberdayaan masyarakat yang bersangkutan sehingga bertujuan untuk menemukan alternatif- alternatif baru dalam pembangunan masyarakat (Mardikanto, 2014). Demikian juga dengan masyarakat yang berada di lingkungan kelurahan Sembungharjo dimana di daerah tersebut banyak potensi yang bisa digali lagi dalam upaya Penumbuhan Usaha baru dengan melakukan pembinaan lingkungan sosial dan pemberdayaan ekonomi masyarakat untuk mendorong pertumbuhan ekonomi daerah.

\section{METODE}

Dalam upaya menumbuhkembangkan wirausaha baru bagi pelaku usaha industri di lingkungan kelurahan Sembungharjo Genuk, supaya tumbuh menjadi wirausaha baru dan mandiri, maka perlu difasilitasi untuk mengembangkan skill yang bisa menggali kreativitas dan potensi sesuai dengan kemampuan wilayah.

Untuk menjadi wirausahawan yang berhasil, maka persyaratan utama yang harus dipenuhi adalah memiliki jiwa dan watak kewirausahaan. Bisnis plan merupakan salah satu unsur penting bagi calon pengusaha untuk memandu atau sebagai pedoman dalam menjalankan suatu unit usaha. Rencana bisnis memuat informasi-informasi penting tentang bisnis yang akan dijalankan antara lain: maksud bisnis, gambaran bisnis anda, rumusan pasar dan program pemasarannya, persiapan teknis operasionalnya, manajemennya serta aspek keuangannya.

Untuk mencapai sasaran tersebut, maka solusi yang diberikan oleh tim pengabdian untuk khalayak sasaran dalam bentuk:

1. Memberikan pelatihan dan pendampingan cara menggunakan kanvas,

2. Mengembangkan model bisnis yang ada sekarang menjadi seperti yang diinginkan

3. Menterjemahkan Rencana Bisnis Untuk Kelompok Usaha menjadi proses bisnis.

Kegiatan pelatihan dan pendampingan program pengabdian bagi masyarakat ini bertujuan untuk:

1. Memberikan pengetahuan tentang model bisnis kanvas.

2. Memberikan pelatihan cara memodelkan dan menuangkan ke dalam bentuk model bisnis kanvas

3. Mengimplementasikan model bisnis kanvas ke bisnis para masyarakat

Diharapkan dari pelatihan, bimbingan teknis dan pendampingan yang dilakukan oleh tim pengabdian Unisbank bagi masyarakat kelurahan Sembungharjo Genuk bisa memberikan motivasi 
untuk membentuk mindset usaha bagi perempuan usaha industri kecil menengah menjadi wirausaha mandiri. Artinya bagi ibu-ibu khususnya di lingkungan kelurahan Sembungharjo Genuk, dapat mandiri memiliki usaha sebagai alternatif matapencarian selain matapencarian utama, dengan memanfaatkan bahan-bahan yang ada untuk bisa diopetimalkan dalam bentuk produk Ecoprint teknik Steamming.

Berdasarkan analisis situasi sebelumnya dan permasalahan yang ada, maka solusi yang ditawarkan dalam pengabdian masyarakat ini adalah dengan melakukan pelatihan dan pendampingan. Dalam pengabdian pada masyarakat ini bentuk kegiatan yang dilakukan adalah pemberian materi pelatihan. Pelatihan dibagi dalam beberapa aktivitas kegiatan yang meliputi:

a. Penjelasan materi analisis SWOT

b. Penjelasan mengenai Model Bisnis Canvas

c. Latihan Pembuatan Model Bisnis Canvas

Adapun urutan pelaksanaan kegiatan dimulai dari:

a. Kegiatan dilakukan secara bersama bertahap yang dimulai dengan paparan materi secara detail tentang generasi model bisnis (Generation Model Bussines).

b. Memberikan gambaran dengan studi kasus dalam bentuk best practice.

c. Implemantasi model bisnis kanvas dengan Game

d. Praktek Pembuatan model bisnis kanvas dengan kasus tiap peserta IKM.

Dalam metode aktivitas Game Bisnis Kanvas Model, peserta akan diajarkan materi dengan urutan berikut:

1. Desain model bisnis dengan panduan skenario

2. Menggali ide

3. Analisa SWOT

4. Menggunakan hasil analisis penilaian SWOT untuk mendesain pilihan model baru.

5. Proses desain model bisnis kanvas

Aktivitas dan kegiatan bisa dilihat gambar 1, gambar 2, gambar 3, gambar 4, dan gambar 5.

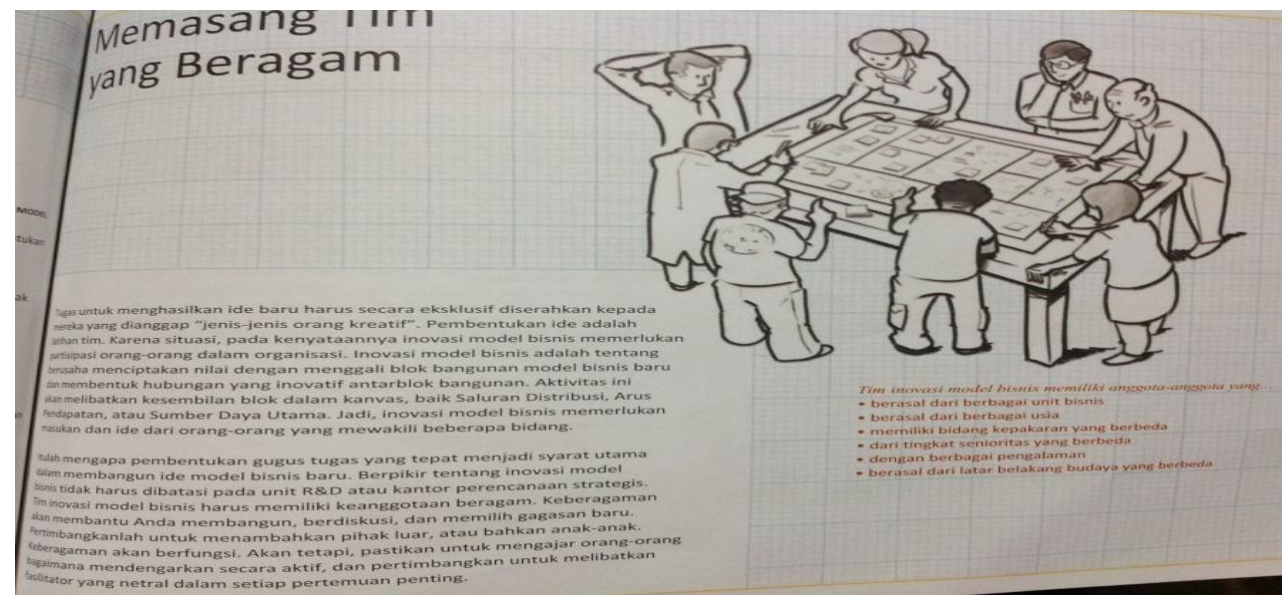

Gambar 1. Tim Rencana Bisnis 


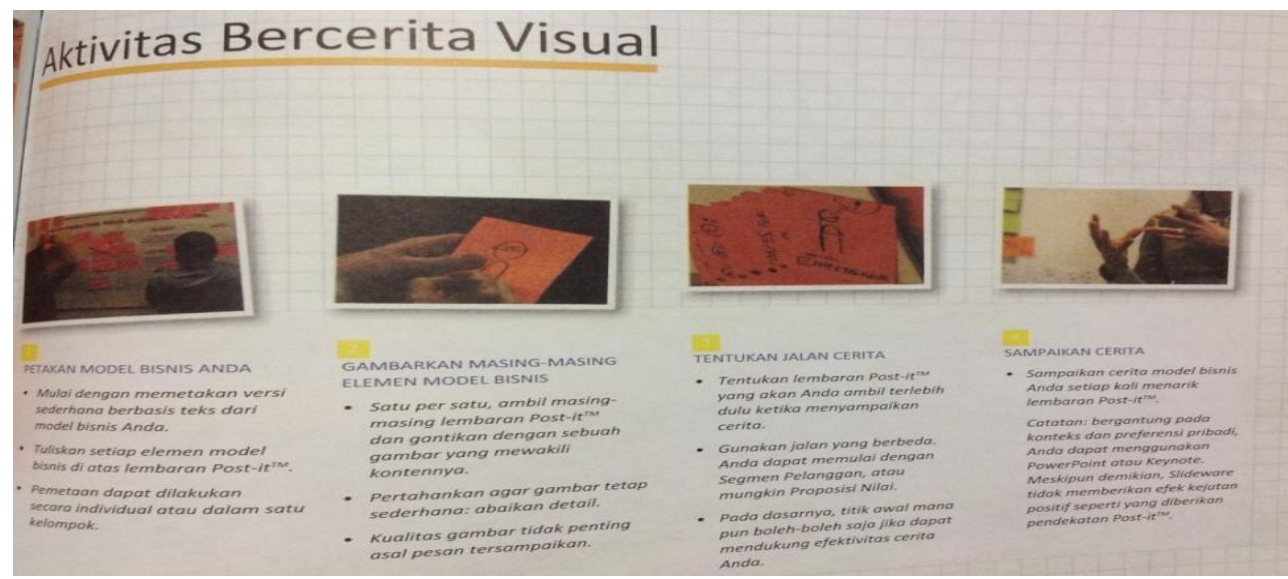

Gambar 2. Aktivitas Tim yang harus dilakukan

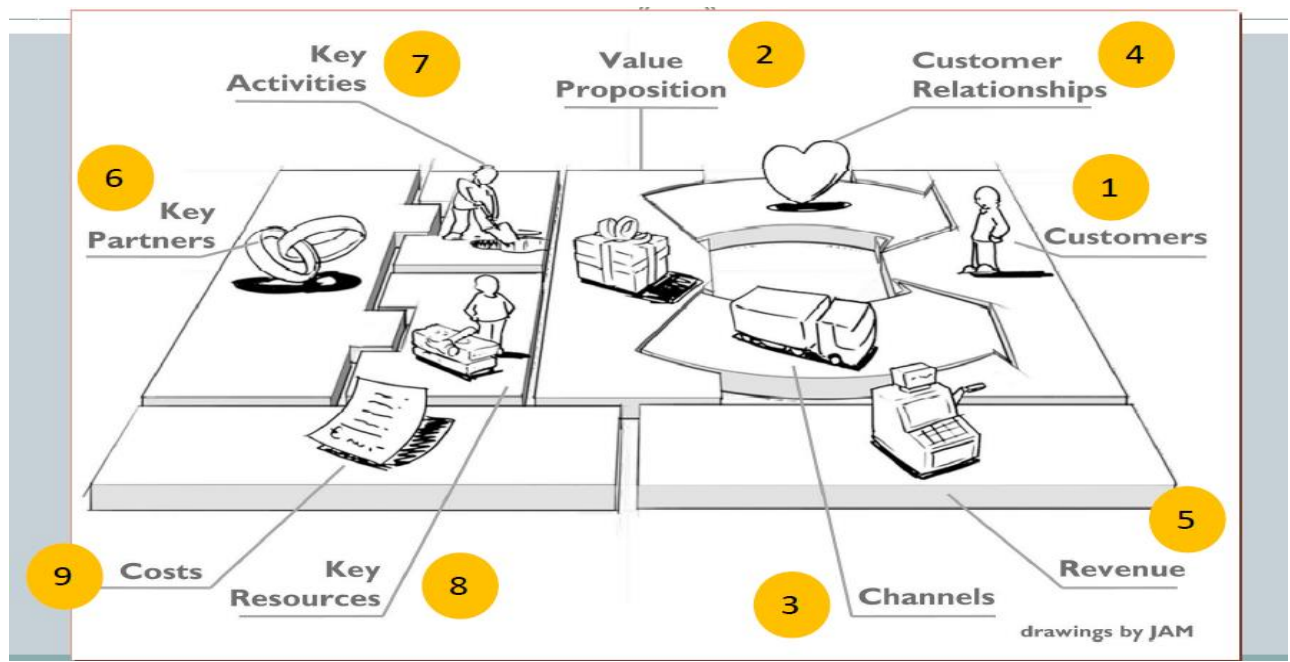

Gambar 3. Blok Bangunan Model Bisnis Kanvas

\section{Customer Segment : Mengetahui Pelanggan}

Mengetahui dengan persis siapa calon pelanggannya maka perlu menjawab pertanyaanpertanyaan tentang umur, jenis kelamin, domisili/tempat tinggal, jenis kebutuhan, jumlah pengeluaran perbulan. Selanjutnya pertanyaan tentang jenis produk atau layanan apa bagi calon pelanggan merupakan kesalahan yang biasa dilakukan oleh pebisnis pemula adalah langsung menentukan bisnis dan baru memutuskan apa yang bisa dijual.

Value Proposition: Apa yang ditawarkan.

Inilah hal utama yang ditawarkan kepada pelanggan. Tentukan bisnis untuk menjawab masalah yang dihadapi konsumen. Jenis usaha apa yang bisa menjawab kebutuhan pelanggan. Jadi yang terpenting Value apa yang ditawarkan sehingga menarik.

\section{Channel: Saluran distribusi.}

Bisnis yang diputuskan, harus ditentukan saluran penjualan, bagaimana cara agar produk/layanan sampai ke pelanggan, Apakah akan dibangun tim penjualan sendiri atau akan memberikan bagian penjualan kepada orang lain seperti distributor/reseller, apakah akan membuka toko sendiri atau membuka counter kecil di dalam toko besar, apakah akan menjual secara online contoh niaga.com atau membuka toko. Maka perlu dianalisis kelebihan dan kekurangan dari setiap pilihan selanjutnya tentukan pilih yag terbaik.

Customer Relationship : Marketing

Sebuah bisnis baru harus diketahui oleh calon pelanggan, karena itu perlu menginfokan kepada public tentang berbagai cara bisa dilakukan, baik online maupun offline. Kegiatan offline adalah kegiatan yang bersifat fisik, misalnya mengadakan event atau gathering, membagikan 
brosur, memasang spanduk atau baliho di jalan. Saat ini kegiatan marketing online adalah kegiatan favorit para pemula bisnis, karena budget yang relative kecil bahkan seringkali gratis. Marketing online ini dapat dilakukan melaui pembuatan blog, facebook atau twitter, hingga memasang iklan di Google Adwords.

\section{Revenue Stream: Sumber Pendapatan}

Sejak awal, perlu menentukan jenis-jenis pendapatan bahwa apakah akan membuat media online dan mendapatkan pendapatan dari iklan, apakah akan membuat toko dan mendapatkan penghasilan dari volume penjualan, apakah akan membuat perusahaan design lalu mendapatkan fee design. Putuskan dan tentukan target pendapatan per bulan. Jangan pernah membuat bisnis tanpa memikirkan rencana pendapatan.

\section{Key Partner : Mitra Utama}

Sukses berbisnis tidak bisa sendirian, harus bekerjasama dengan banyak pihak lainnya. Sehingga tentukan dari awal bisnis memerlukan investor untuk permodalan atau tidak, apakah perlu mengadakan perjanjian kerjasama khusus dengan distributor, apakah "selebriti" dan memberikan persentase saham kepada selebriti tersebut, menggandeng partner yang melengkapi kemampuan yang kita miliki akan meningkatkan peluang keberhasilan bisnis. Untuk itu pikirkan untuk menjalin kolaborasi dengan partner.

\section{Key Activities : Kegiatan Bisnis}

Kegiatan-kagiatan apa saja yang akan dilakukan tergantung pada apa (produk atau jasa) yang akan ditawarkan kepada konsumen, seperti usaha kursus bahasa inggris dengan value propositionnya pengajaran yang menyenangkan dan materi pengajaran berkualias maka kegiatan bisnisnya adalah promosi, training guru, dan materi yang selalu diperbaharui. Kegiatan - kegiatan bisnis diuraikan secara detail dan logis.

\section{Key Resources : Sumberdaya Utama}

Menjalankan bisnis umumnya tidak bisa sendirian namun memerlukan staff. Sejak awal tentukan banyak dan jenis keahlian apa yang diperlukan oleh karyawan. Selain staff/SDM, juga memerlukan sumber daya non manusia seperti sewa toko/kantor perbulan, komputer dan harga totalnya, membuat meja counter atau display untuk penjualan.

\section{Cost Structure : Struktur Biaya}

Semua hal yang dilakukan dari tahap 6 hingga 8 memerlukan biaya, Tentukan semua komponen biaya secara rinci, benar dan logis. melakukan analisis finansial secara seksama, selanjutnya putuskan untuk menentukan kelayakan rencana-rencana bisnis tersebut yang menguntungkan.

The Business Model Canvas

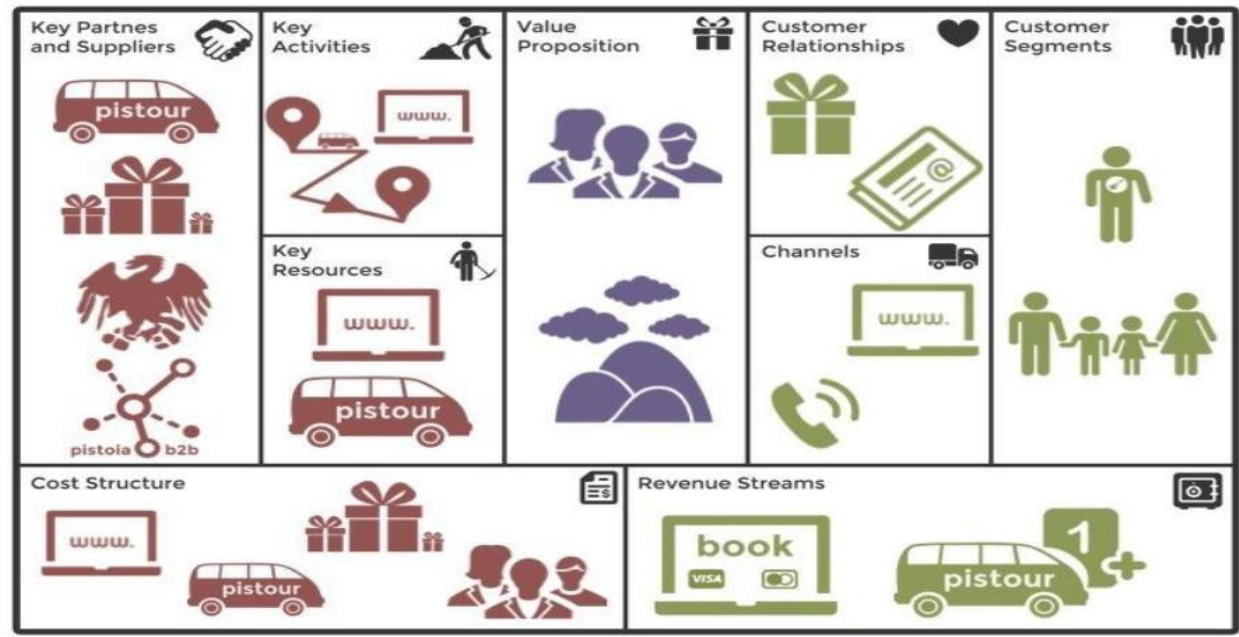

Gambar 4. Template Model Bisnis Kanvas 


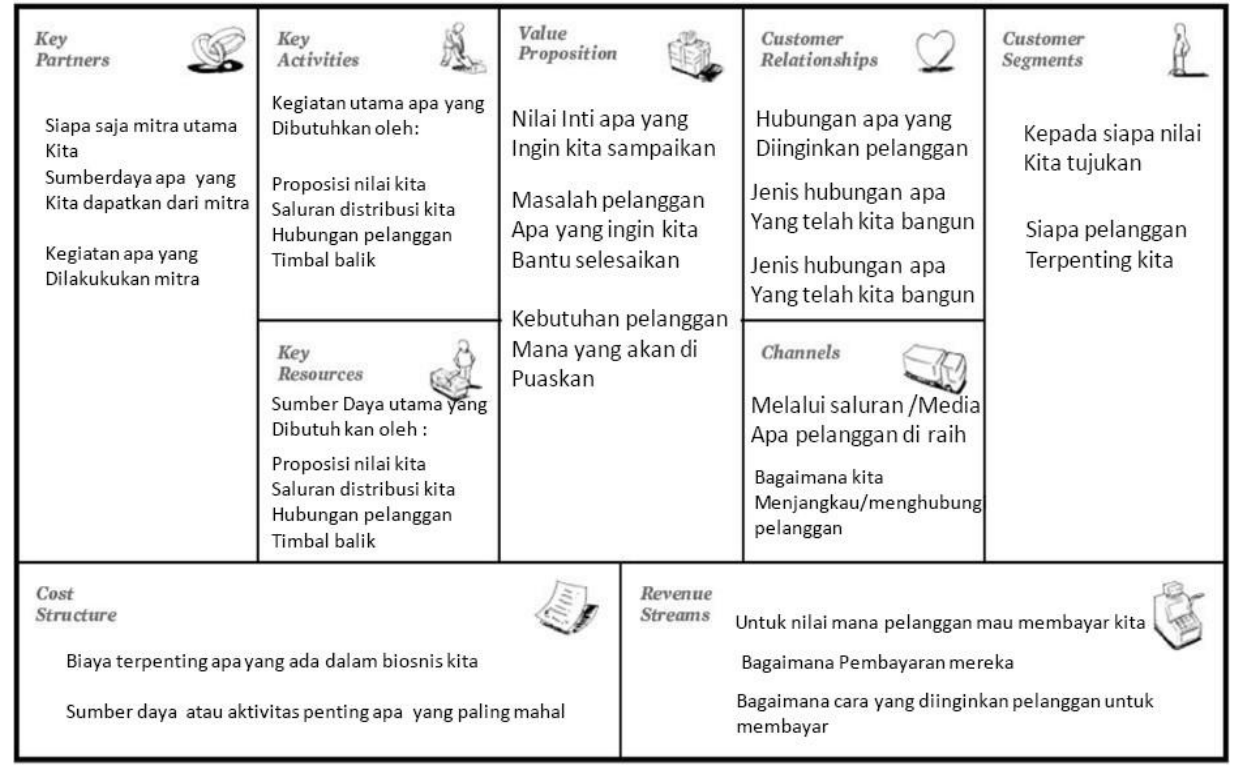

Gambar 5. Best Practice Model Bisnis Kanvas

\section{HASIL DAN PEMBAHASAN}

Bentuk kegiatan pengabdian masyarakat ini adalah memberi materi tentang model bisnis kanvas dan memberikan contoh serta mengaplikasikan model bisnis pada template yang sudah disediakan. Adapun pelaksanaan kegiatan pelatihan di kediaman bapak RT 03 RW 02 Kelurahan Sembungharjo Kecamatan Genuk. Peserta pelatihan diikuti oleh ibu-ibu di wilayah kelurahan Sembungharjo. Waktu pelaksanaan Kegiatan Pengabdian Masyarakat mulai dari persiapan materi hingga pembuatan laporan akhir memerlukan waktu 2 bulan (30 Mei s/d 30 Juli 2020). Persiapan, koordinasi, materi dan hal lainnya membutuhkan waktu selama 4 minggu. Penyusunan laporan, evaluasi membutuhkan waktu selama 2 minggu. Pelaksanaan pelatihan dilakukan secara bertahap yaitu:

- Peserta diberi 1 lembar Kertas dan alat tulis (post it, ballpoint, penggaris)

- Membuat 9 Elemen / Layer Model Bisnis Canvas yang diisi sesuai dengan rencana bisnis tiap kelompok

Peserta pelatihan mempraktekkan secara langsung materi yang diberikan mengenai BMC. Pelatihan Model Bisnis Kanvas dilakukan dalam beberapa tahap yang dimulai dari tahap persiapan, pelaksanaan dan finishing (penyelesaian).

Adapun tahapan-tahapan yang dilakukan dalam pelaksanaan pelatihan supaya bisa tepat sasaran sesuai dengan tujuan pengabdian adalah sebagai berikut:

1. Tahap Persiapan

a) Mendata kebutuhan peserta pelatihan dengan menawarkan pelatihan ke ibu-ibu Dikelurahan Sembungharjo Genuk

b) Mempersiapkan modul pelatihan

c) Membuat RAB untuk pelaksanaan

d) Pembelian bahan dan peralatan seperti kertas/ ballpoint/ post it/ penggaris

e) Menghubungi pihak terkait mengenai lokasi yang akan dijadikan lokasi pelatihan

2. Tahap Pelaksanaan

a) Pelaksanaan dibagi dalam 2 sesi, sesi 1 peserta diberi materi Analisis SWOT dan BMC

b) Sesi 2 peserta diminta membuat Model Bisnis Canvas

3. Tahap Penyelesaian

a) Mendokumentasikan semua aktifitas kegiatan selama pelatihan,

b) Membersihkan ruangan dan merapikan jangan sampai menjadi sampah di ruangan dan mengembalikan pada posisi semula ruangan. 
Evaluasi kegiatan dilakukan setelah berakhirnya pelaksanaan. Kegiatan pengabdian ini dinyatakan berhasil sesuai dengan rencana dapat dilihat berdasar keterlibatan peserta dan antusias selama mengikuti kegiatan dan bisa menghasilkan Bisnis Model Canvas. Adapun indikator keberhasilan kegiatan tersebut adalah:

1. Peserta dapat memahami analisis SWOT dalam menjalankan usaha

2. Peserta dapat membuat model bisnis kanvas.
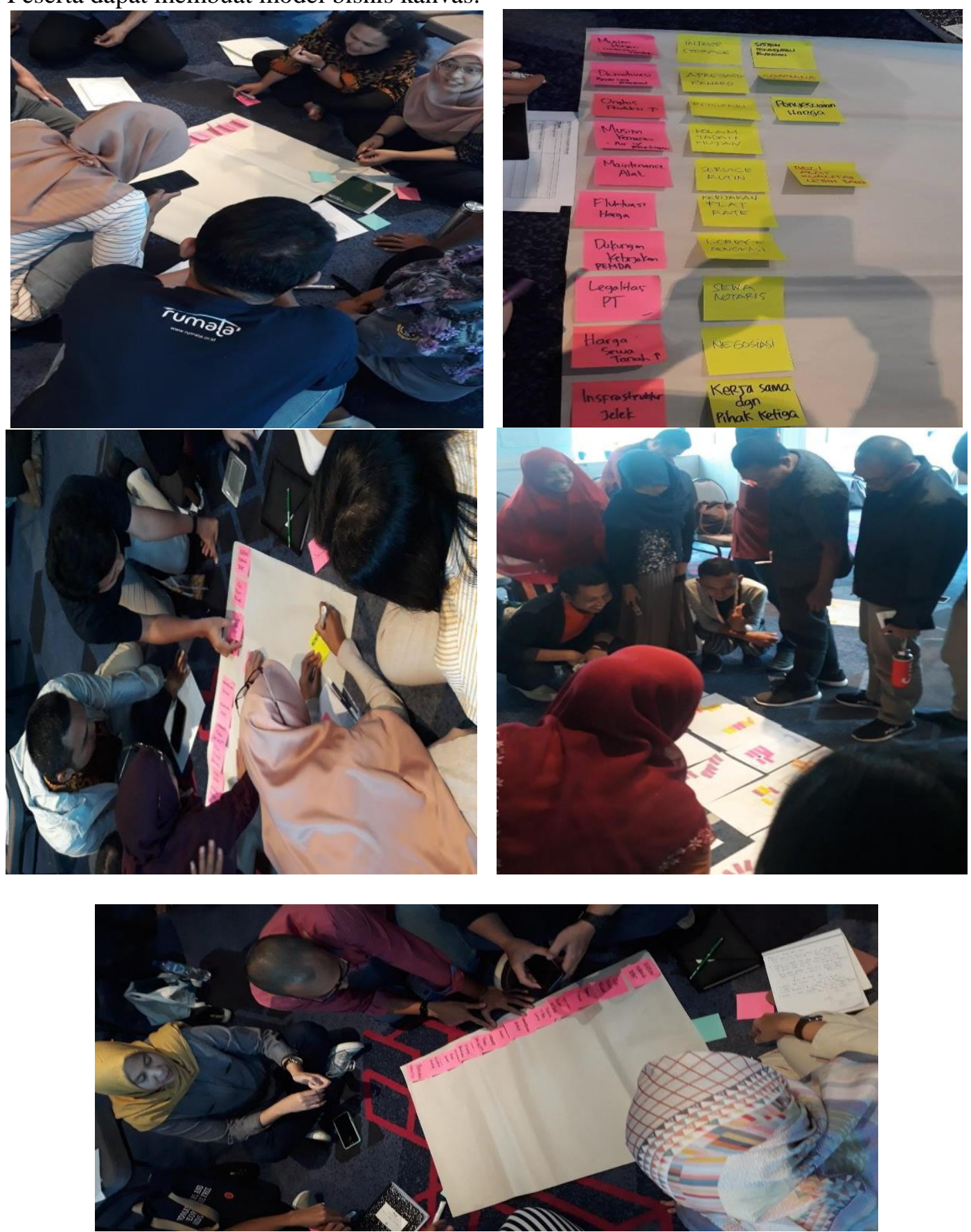

Gambar 6. Pelaksanaan Kegiatan

\section{KESIMPULAN}

Kegiatan pelatihan penumbuhan wirausaha baru diharapkan bisa memberikan wawasan tentang membangun karakter wirausaha, membuat perencanaan bisnis dan target usaha. Pelatihan ini diharapkan bisa menjadi penyemangat para ibu untuk bisa berwirausaha.

Pelatihan diharapkan bisa dikembangkan dengan memberikan pelatihan berupa pembuatan anggaran untuk memulai usaha dan pembukuan sederhana dari usaha yang akan dijalankan 
sehingga akan mengarah pada pembuatan laporan keuangan dan masalah perhitungan pajak hingga sampai pelaporan pajak.

\section{DAFTAR PUSTAKA}

Coes, Bastian. (2014). Critically Assessing The Strengths and Limitations of The Business Model Canvas. Disertasi Master Business Administration Enschede: University of Twente.

Dudin, Mikhail N et al. (2015). The innovative Business Model Canvas in the System of Effective Budgeting. Asian Social Science, Vol.II, 290-296. Toronto: Canadian Center of Science and Education.

Freddy Rangkuti (2015), Analisis SWOT: Teknik Membedah Kasus Bisnis - Cover Baru, Gramedia, Jakarta

Hisrich D. Robert, Michael P. Peters, dan Dean A. Shepherd (2005). Entrepreneurship, 6th edition. Mcgraw-Hill.

Osterwalder, A dan Pigneur, Y. (2017). Business Model Generation : Pedoman bagi para Visioner, Penggerak Perubahan, dan Pendobrak. Jakarta : PT Elex Media Komputindo.

Tim PPM Manajemen (2012), Business Model Canvas : Penerapan di Indonesia, PPM, Jakarta 